\title{
Roundabout Justice: A COMMENT ON DANYLUK V. AINSWORTH TECHNOLOGIES
}

\author{
DAvid W. ElLIOTT
}

\section{INTRODUCTION}

The Supreme Court took a roundabout path to justice in Danyluk v. Ainsworth Technologies.' When a fired employee sought to relitigate issues from a flawed administrative decision, the Supreme Court went to great lengths to say that the doctrine of issue estoppel could apply, and then refused to apply it. Because the doctrine was not applied here, the employee was able to pursue her claim to unpaid wages and commissions in the ordinary courts. Arguably, the end result of this case was a balanced resolution of the competing needs of administrative justice and finality. To reach this result, though, the Court adopted a complex notion of "judicial" decisions, drew fine distinctions between different categories of jurisdiction, and took a parallel rather than integrated approach to the doctrines of administrative finality. This comment looks at the Court's approach to these three issues. It suggests that there was a simpler path available, one that may be still worth considering.

\section{FACTS}

Ms. Danyluk was embroiled in a dispute with her employer Ainsworth Technologies over a claim for $\$ 300,000$ in unpaid wages, including commissions. Ms. Danyluk filed a complaint about the wages and commissions under the Employment Standards Act. ${ }^{2}$ She had a phone conversation and a one-hour meeting with an ESA officer, and she provided supporting documents. After Ms. Danyluk filed the complaint, Ainsworth dismissed her. She decided to sue Ainsworth for wrongful dismissal and for the unpaid wages and commissions, in a civil action for damages in the ordinary courts.

A year after Ms. Danyluk filed her complaint, the $E S A$ officer rejected her claim to the wages and commissions. ${ }^{3}$ Ms. Danyluk then learned that the officer had received submissions and documents from Ainsworth without communicating them to her or giving her a chance to respond to them.

The ESA allowed for an appeal from a decision of an ESA officer if the employee applied for it, and if the ESA Director exercised his or her discretion to establish it. ${ }^{4}$ The

Associate Professor of Law, Department of Law, Carleton University.

Danyluk v. Ainsworth Technologies (2001), 201 D.L.R. (4th) 193, online: QL (SCJ), rev'g (1998), 42 O.R. (3d) 235 (C.A.), aff'g (10 June 1996), Ontario 94-CQ-49562/94-CQ-49562 (Gen. Div.) McCombs J. [hereinafter Danyluk].

R.S.O. 1990, c. E-14, as am. [hereinafter ESA].

However, the officer did find that Ms. Danyluk was entitled to two weeks termination pay.

Although the appeal was called a "review," the $A c t$ contemplated a full de novo reconsideration.

Section 67 the $A c l$ said that

(2) An employee who considers himself or herself aggrieved by the refusal to issue an order

to an employer or by the issuance of an order that in his or her view does not include all of 
$A c t$ also said that the $E S A$ process was without prejudice to whatever common law redress an employee might seek. ${ }^{5}$ Instead of taking the appeal route, or applying for judicial review, Ms. Danyluk resolved to continue with her civil action. Ainsworth ${ }^{6}$ moved to have a motions judge strike out the wages and commissions part of the action on the ground that it was barred by the doctrine of issue estoppel.

In response, Ms. Danyluk argued that issue estoppel cannot and should not be imposed where an administrator has breached the rules of natural justice. The ESA officer had heard Ainsworth's side of the story without giving her any opportunity to know or reply to the case against her. As a result, she said, the officer failed to make a judicial decision and to treat Ms. Danyluk fairly.

\section{BACKGROUND}

Issue estoppe ${ }^{7}$ is one of two main forms of the common law public policy doctrine of res judicata. ${ }^{8}$ Issue estoppel provides that where there has been a final judicial decision on an issue by an adjudicator of competent jurisdiction, the same parties or their privies cannot relitigate that issue. ${ }^{9}$ The doctrine is intended to ensure finality, to minimize

the wages or other entitlements to which he or she is entitled may apply to the Director...

(3) Upon receipt of an application for review, the Director may appoint an adjudicator who shall hold a hearing.

(5) The adjudicator who is conducting the hearing may with necessary modifications exercise the powers conferred on an employment standards officer under this Act and may make an order with respect to the refusal or an order to amend, rescind or affirm the order of the employment standards officer.

Section $6(1)$ of the $A c t$ said that "No civil remedy of an employee against his or her employer is suspended or affected by this Act."

" References to actions and arguments of "Ainsworth" and to "Mrs. Danyluk" in the litigation are to Ainsworth Technologies Inc. (joined by Ainsworth Electric Co. Limited and thirteen Ainsworth officers) and Ms. Danyluk, acting through their respective lawyers.

The Supreme Court provides a good short description of issue estoppel, its origins, its aims, and its evolution in Danyluk, supra note 1 at paras. 18-22. See also D.J. Mullan, Administrative Law (Toronto: Irwin Law, 2001) at 472-80 and the authorities in infra note 8 (all prior to the Supreme Court's decision in Danyluk).

* Known as estoppel per rem judicatam in regard to its effect of barring relitigation and as the doctrine of merger, in regard to its effect of barring the same relief against the same party. On res judicala, see G.S. Bower \& Sir A. Kingcome Turner, The Doctrine of Res Judicala, 3d ed. by K.R. Handley (London, U.K.: Butterworths, 1996); K.R. Handley, "Res Judicata: General Principles and Recent Developments" (1999) 18 Aust. Bar Rev. 214; D.J. Lange, The Doctrine of Res Judicata in Canada (Markham. Ont.: Butterworths, 2000).

Issue estoppel can be distinguished from the other main form of estoppel per rem judicatam, cause of action estoppel. This is a claim that all the legal rights and obligations - not just a single issue or set of issues - in a controversy between parties have been disposed of in an earlier judgment and should not be relitigated between them.

In Danyluk, supra note 1, the Court quoted from two classic Canadian statements about issue estoppel and its conditions. At para. 24 it cited the definition by Middleton J.A. of the Ontario Court of Appeal in McIntosh v. Parent, [1924] 4 D.L.R. 420 at 422 :

When a question is litigated, the judgment of the Court is a final determination as between the parties and their privies. Any right, question, or fact distinctly put in issue and directly determined by a Court of competent jurisdiction as a ground of recovery, or as an answer to a claim set up, cannot be re-tried in a subsequent suit between the same parties or their privies, 
wasteful litigation and potentially inconsistent decisions, and to shield winning parties from undue harassment from the losers. ${ }^{10}$ In the administrative context it helps protect tribunal advantages such as speed, expertise, and informality against erosion by formal proceedings in ordinary courts. Although issue estoppel is derived from common law rather than equity," it resembles equity in its elevation of fairness over rigid formality and technicality. ${ }^{12}$

At the same time, issue estoppel has numerous limits. ${ }^{13}$ For example, it applies to court or "judicial" decisions. The prior decision must have been authorized, and it must be final. The issue must have been fundamental to the prior decision. The same parties must be involved in both proceedings. Moreover, the advantages of finality should not be outweighed by injustice to individual parties.

Although issue estoppel can apply to bodies other than ordinary courts, pre-Danyluk case law had difficulties adapting the doctrine to the administrative process. It was unclear what kinds of administrative decisions should attract the doctrine. It was uncertain as to what should be considered sufficiently "final" or "judicial" in an administrative law context. There was no consensus on how issue estoppel should relate to other administrative law finality doctrines, such as the rule against collateral attack and the principle of alternative remedies. ${ }^{14}$ By the 1990 s, then, there was a growing list of conflicting decisions on the role of issue estoppel in administrative law. ${ }^{15}$

though for a different cause of action. The right, question, or fact, once determined, must, as between them, be taken to be conclusively established so long as the judgment remains.

At para. 25 the Court quoted Dickson J.'s statement of the preconditions to the operation of issuc estoppel in Angle v. Canada (M.N.R.), [1975] 2 S.C.R. 248 at 254 [hereinafter Angle]:

(1) that the same question has been decided;

(2) that the judicial decision which is said to create the estoppel was final; and,

(3) that the parties to the judicial decision or their privies were the same persons as the parties

to the proceedings in which the estoppel is raised or their privies. See the lucid description in Danyluk, ibid. at paras. 18-21.

Ibid. at para. 63.

See generally C.K. Allen, Law in the Making, 7th ed. (Oxford: Oxford University Press, 1964), c. v. On equity and formal legal rules, see P. Baker \& P. Langan, Snell's Principles of Equity, 28th ed. (London, U.K.: Sweet \& Maxwell, 1982) at 40, referring to "equity's impatience with mere technicalities," and Lord Denning's statement (in regard to the historical origins of the right of equitable set-off) that "the courts of equity, as was their wont, came in to mitigate the technicalities of the common law": Federal Commerce \& Navigation Co. v. Molena Alpha Inc., [1978] I Q.B. 927 at $974 \mathrm{E}$ (C.A.). As will be seen in Danyluk, issue estoppel is itself a source of technicality. For the main restrictions. see Angle, supra note 9 at 254; Bower \& Kingcome Turner, supra note 8, cc. II-VII; Lange, supra note 8. c. 2; and Danyluk, supra note I at paras. 24-36.

Other possible finality concepts, not considered here, include the doctrine of abuse of process (see Lange, ibicl., c. 7; United States v. Cobb, [2001] 1 S.C.R. 587 at para. 37) and the doctrine of functus officio, which prevents a decision-maker from reconsidering or reopening its own decision in the absence of compelling reasons or statutory authorization (see Mullan, supra note 7 at 384-89).

See, e.g., Canada (A.G.) v. Symtron Systems, [1999] 2 F.C. 514 (C.A.) at 539, n. 21; Susan Shoe Industries v. Ricciardi (1994), 18 O.R. (3d) 660 (C.A.); Rasanen v. Rosemount Instruments (1994), 112 D.L.R. (4th) 683, leave to appeal to S.C.C. refused (1994), 19 O.R. (3d) xvi; Wong v. Shell Canada (1995), 174 A.R. 287 (C.A.), leave to appeal to S.C.C. refused [1995] S.C.C.A. No. 551 (12 September 1996), online: QL (SCCA); Braithwaite v. Nova Scotia Public Service Long Term Disability Plan Trust Fund (1999), 176 N.S.R. (2d) 173 (C.A.); Minott v. O'Shanter Development 
One field most affected was that of employment law, including the federal unemployment insurance process and employment standards processes in the provinces. ${ }^{16}$ Typically, employment standards processes include informal structures for resolving disputes about the dismissal of non-union employees and include administrative appeal provisions. ${ }^{17}$ In this context it was relevant to ask if and when an employee could sue an employer for wrongful dismissal and wages in the ordinary courts after losing on these same issues before an employment standards officer. These issues, in turn, seemed to lead right back to the broader unresolved questions about the issue estoppel doctrine.

These questions surfaced at a time of great change in Canadian administrative law. In the last decades of the twentieth century, the Supreme Court presided over a revolt against formalism in judicial review. ${ }^{18}$ In areas such as procedural and substantive review and collateral attack, it has adopted a factor-based contextualist approach to intervention. ${ }^{19}$ The Court's focus is away from concepts and classifications and toward the open, reasoned exercise of judicial discretion. This shift to discretion has left unanswered many questions about the role of old notions such as jurisdiction.

\section{DECISIONS}

Ainsworth's motion to strike was heard by McCombs J. of the Ontario Court's General Division. In an unreported decision, ${ }^{20} \mathrm{McCombs} \mathrm{J}$. agreed to strike out the part of Ms. Danyluk's claim that related to the unpaid wages and commissions. ${ }^{21}$ McCombs J. held that issue estoppel prevented relitigation of this issue. For him, the sole question was whether the ESA officer's decision was final. He said it was final because Ms. Danyluk had not appealed it or challenged it by way of judicial review. Ms. Danyluk appealed his decision to the Ontario Court of Appeal.

The Court of Appeal ${ }^{22}$ said that the ESA officer had violated the rules of natural justice and thus failed to act judicially. However, the Court held that breach of natural justice should not preclude issue estoppel where there is an avenue of appeal available.

Co. (1999), 42 O.R. (3d) 321 (C.A.); Heynen v. Frito Lay Canada (1999), 179 D.L.R. (4th) 317 (Ont. C.A.).

See generally G. England et al., eds., Employment Law in Canada, 3d ed., looseleaf (Markham, Ont.: Butterworths, 1989).

17 For an overview of the purpose and procedure of the legislation in Ontario, see Danyluk, supra note 1 at paras. 27-29. The Court describes the procedure as rapid, inexpensive, "rough-and-ready," and "wholly inappropriate ... to the definitive resolution of a contractual claim of some legal and factual complexity": ibid. at paras. 28-29.

See H.W. MacLauchlan, "Transforming Administrative Law: The Didactic Role of the Supreme Court of Canada" (2001) 80 Can. Bar Rev. 281, commenting on the development of Canadian administrative law between 1970 and 2000.

See, e.g., Baker v. Canada (Minister of Citizenship and Immigration), [1999] 2 S.C.R. 817 (procedural and substantive review) and R. v. Consolidated Maybrun Mines, [1998] I S.C.R. 706 (collateral attack) [hereinafter Maybrun]. 
It said that the rule against judicial review where there is an adequate alternative and the rule against collateral attack underpinned a more general principle: the idea that parties should pursue the remedies established by the legislature. Because there had been an adequate alternative remedy here, and because the other issue estoppel requirements were met, the doctrine should apply in this case. Ms. Danyluk appealed to the Supreme Court of Canada.

The Supreme Court ${ }^{23}$ also held that the conditions for issue estoppel were present. The parties and the question were the same, and the ESA officer's decision was final as the administrative appeal route had not been taken. Moreover, the ESA officer's decision was "judicial." The officer had judicial powers and made a judicial decision in a judicial manner. Nor did the breach of natural justice render the decision void and negate its status as a valid judicial decision. However, the Court said the application - as opposed to the existence - of issue estoppel depends on a court's assessment of a variety of factors. The most important was that Ms. Danyluk's claim had not been properly considered and adjudicated. As a result, the Court decided not to apply issue estoppel. Ms. Danyluk was considered free to proceed with her claim to unpaid wages and commissions in the General Division of the Ontario Court of Justice.

\section{ANALYSIS}

Danyluk illustrates many of the strengths of the Supreme Court's modern contextualist and discretionary approach. The Court managed to do justice to a fired employee while recognizing the special policy needs of administrative finality. It developed a thoughtful and transparent list of practical factors to guide judicial intervention in an evolving field of law. On the other hand, the Court's decision in Danyluk was arguably more complex and technical than it needed to be. In particular, the Court might have avoided the complexities of issue estoppel, and it might have taken a simpler approach to administrative finality. To see how this is so, it is necessary to examine how the Court approached some of the key requirements and contextual elements of the issue estoppel doctrine.

\section{A. THE "JUDICIAL" REQUIREMENT}

One of the first main issues in Danyluk was the requirement of a "judicial" decision as a condition of issue estoppel. This term has some valid historical and practical roots. ${ }^{24}$

Danyluk, supra note 1, McLachlin C.J.C. and lacobucci, Major, Bastarache, Binnie, Arbour, and LeBel JJ. Binnie J. delivered the opinion of the Court.

24

Like a number of other common law finality doctrines, issue estoppel originally developed in the context of proceedings in ordinary courts: Danyluk, supra note 1 at para. 22. When judges later applied issue estoppel to administrative decisions, they tended to restrict it to situations that resembled ordinary court proceedings. In this new context, the term "judicial" was no longer selfevident but became used as a marker to help identify and justify situations where the doctrine should be applied.

This use of "judicial" was not unusual. Judges have used the term to extend other court-based doctrines, such as the rules of natural justice, to administrative bodies. This is not surprising as there is a self-limiting rationale at its core. The assumption is that where the legislature entrusts 
Issue estoppel itself developed in the context of court decisions and presupposes at least a minimal adjudicative context. However, "judicial" is a coat of many colours and has a knack for generating case law confusion. ${ }^{25}$ If it is used in issue estoppel, it must be given a definite, defensible, and coherent meaning.

The Supreme Court started doing this in Danyluk. It said that "judicial" refers to the application of an objective legal standard to findings of fact $^{26}$ and excludes investigative $e^{27}$ and legislative functions. ${ }^{28}$ This was a good start as each of these elements can be related to the basic functions of issue estoppel. The objective legal standard requirement would catch most administrative decisions other than those that are purely discretionary and are limited to specific circumstances. This is consistent with the focus of issue estoppel on the finality of legal standards, as opposed to one-time settlements. The exclusion of investigative functions reflects the concern of issue estoppel to protect final decisions, and the exclusion of legislative functions limits the context to specific parties. This approach to "judicial" has coherence as well, as its criteria are all concerned with one form of measurement (function) and do not include other forms, such as fairness or fault.

Applying this functional definition, the Court might have rejected Ms. Danyluk's argument that breach of natural justice removed the "judicial" requirement on the ground that the relevant adjudicative functions remained. Indeed, at one point, the Court said that "[f]lawed the decision may be, but 'judicial' [as distinguished from administrative or legislative] it remains." 29

But this is not what happened. The Court went on to consider a separate precondition for issue estoppel, the requirement of a prior decision within jurisdiction. It then treated jurisdiction as an aspect of the "judicial" requirement. In effect, the Court said that issue

administrators with court-like functions, it intended administrators to offer court-like protections as well. The converse, of course, is that where administrators do not act much like courts, these presumed protections should be minimal or nil. The classic example of this flexible use of the court analogy is Cooper v. Wandsworth Board of Works (1863), 14 C.B. (N.S.) 180, 143 E.R. 414 (Court of Common Pleas). In theory, the approach tends to limit courts to the kind of common law protections they are used to imposing on themselves, and the entire approach is subject to legislative signals to the contrary.

The term "judicial" can describe a multitude of different features. It can describe the exercise of general functions or compliance with specific procedural requirements. To make things worse, the term can be used in either a descriptive or prescriptive sense. For example, in the context of natural justice and the prerogative remedy of certiorari, confusion over whether "acting judicially" simply described a situation in which base judicial requirements had been met, or prescribed additional judicial requirements, had a significant effect on the scope of Anglo-Canadian judicial review in the first part of the twentieth century. On the history of the term in natural justice jurisprudence: see D.P. Jones \& A.S. de Villars, Principles of Administrative Law, 3d ed. (Scarborough: Carswell, 1999) at 187-215. Although the "judicial" notion may still survive as a kind of unarticulated assumption at the core of natural justice, overt use of the term is now strictly limited.

26. Danyluk, supra note 1 at para. 41.

27 Ibid. at para. 40. The exclusion of legislative functions is redundant as it is already caught by the separate requirement that decisions attracting issue estoppel must be "final." 
estoppel requires the adjudicative features described above and the presence of jurisdiction at the very beginning of an administrative decision. This stretches the meaning of "judicial," mixes functional features with actual results, and invites confusion.

\section{B. THE REQUIREMENT OF JURISDICTION}

The requirement of jurisdiction was another major issue in Danyluk. Issue estoppel protects only a decision that was made within the competence or jurisdiction of the decision-maker. ${ }^{30}$ Like the "judicial" requirement for issue estoppel, jurisdiction has a history of problems. In the past courts have sometimes used jurisdictional labels as substitutes for more concrete exploration of legislative intent. ${ }^{31}$ They have drawn fine distinctions between reviewable jurisdictional and non-jurisdictional defects. ${ }^{32}$ Sometimes they have adopted rigid approaches to the effect of jurisdictional invalidity. ${ }^{33}$ Partly because of problems like these, the Supreme Court has given jurisdiction a more modest and flexible role in modern judicial review. The Court has tended to treat jurisdiction more as a consequence than a determinant of judicial review. ${ }^{34}$ It has virtually eliminated the old category of non-jurisdictional error..$^{35}$ Today, then, it is arguable that all common law judicial review defects are jurisdictional in result. If so, this ends the need for distinctions between jurisdictional and non-jurisdictional reviewable defects and their

Bower \& Kingcome Turner, supra note 8, c. 4; Handley, supra note 8 at 215.

For some general criticisms, see J.M. Evans, "Developments in Administrative Law: The 1984-85 Term" (1986) 8 Supreme Court L.R. 1 at 33-35; B. Langille, "Judicial Review, Judicial Revisionism and Judicial Responsibility" (1986) 17 R.G.D. 169 at 197-214; Wilson J., dissenting in National Corn Growers Assn. v. Canada (Import Trib.), [1990] 2 S.C.R. 1324, referring to the Evans and Langille criticisms at para. 23; J.M. Evans et al., Administrative Law: Cases, Text, and Materials, 4th ed. (Toronto: Emond Montgomery, 1995) at 816-21.

See generally ibid.

See Jones \& de Villars, supra note 25 at 131-32 and 404-406.

This altered emphasis was reflected in the following comment by Bastarache J. in Pushpanathan v. Canada (Minister of Citizenship and Immigration), [1998] I S.C.R. 982 at para. 28 [hereinafter Pushpanathan]:

[I]t should be understood that a question which "goes to jurisdiction" is simply descriptive of a provision for which the proper standard of review is correctness, based upon the outcome of the pragmatic and functional analysis. In other words, "jurisdictional error" is simply an error on an issue with respect to which, according to the outcome of the pragmatic and functional analysis, the tribunal must make a correct interpretation and to which no deference will be shown.

Similarly, the Court has said that a decision which is found (by the pragmatic and functional analysis) to be patently unreasonable results in a loss or excess of jurisdiction: CAIMAW. Local $14 \mathrm{v}$. Paccar of Canada, [1989] 2 S.C.R. 983 at para. 19 [hereinafter Paccar]; and Syndicat des employés professionnels de l'Université du Québec à Trois-Rivieres v. Université du Québec à Trois-Rivières, [1993] I S.C.R. 471 at para. 34. A breach of natural justice is normally regarded as resulting in a loss of jurisdiction: Supermarchés Jean Labrecque Inc. v. Flamand, [1987] 2 S.C.R. 219 at para. 54 [hereinafter Flamand]; and R. v. Russell, [2001] S.C.J. No. 53 at para. 20, online: QL (SCJ) [hereinafter Russell] (quaere, whether Danyluk changes this situation in any way?). Presumably, an unreasonable decision where the reasonableness standard applied would also result in a loss of jurisdiction for the purposes of judicial review, although there does not yet seem to be Supreme Court authority on this point.

35 The new standard of correctness appears to subsume common law error of law on the face of the record. Where the correctness standard applies, an incorrect decision results in an absence of jurisdiction: Pushpanathan, ibid. 
consequences. ${ }^{36}$ As well, there is a general tendency to replace rigid with relative concepts of invalidity. ${ }^{37}$

Despite its lower profile today, jurisdiction can still play a general role in judicial control. ${ }^{38}$ By offering redress for unlawful administrative action, judicial control serves the rule of law. ${ }^{39}$ When judicial control is expressed in terms of statutory power or jurisdiction, it highlights the democratic principle as well. This principle requires that government, including the administrative process, should be ultimately under the control of citizens. ${ }^{40}$ In Canada this control is exercised through elected representatives whose main legal tool is the statute. Many administrative powers are coercive, and most coercive government powers can be exercised only by statute..$^{41}$ By focusing judicial intervention on the issue of statutory authorization, then, the idea of jurisdiction links judicial control not only to citizen redress but also to citizen control.

The virtual disappearance of non-jurisdictional error of law on the face of the record has cleared the way for an end to the confusing void/voidable distinction.

See discussion of void and voidable, below.

The context here is that of subconstitutional control such as judicial review and actions for damages, not the direct application of Charter or other formal constitutional norms. For another discussion of the contemporary role of jurisdiction see Mullan, supra note 7, c. 3. In the different context of English administrative law, see the debates in C. Forsyth, ed., Judicial Review and the Constitution (Oxford, U.K.: Hart Publishing, 2000).

This underlying constitutional principle requires, inter alia, that government should act according to law. "A third aspect of the rule of law is, as recently confirmed in the Provincial Judges Reference, [[1997] 3 S.C.R. 3 at para. 10], that 'the exercise of all public power must find its ultimate source in a legal rule."': Reference Re Secession of Quebec, [1998] 2 S.C.R. 217 at para. 71.

4) See Reference Re Secession of Quebec, ibid., describing democracy, inter alia as "[t]he consent of the governed" (at para. 67) and saying that democracy has been interpreted historically to mean "the process of representative and responsible government and the right of citizens to participate in the political process as voters" (at para. 65). See also the Provincial Judges Reference, ibid., referring to "Parliamentary democracy" as an underlying constitutional principle (at para. 101). A related principle, is that of limited Parliamentary sovereignty. This is the principle that, subject to the Constitution, the powers of the Canadian legislatures are legally supreme.

See, e.g., the Case of the Proclamations (1610), 12 Co. Rep. 74, 77 E.R. 1352 (K.B.) and Reference Re Anti-Inflation Act, [1976] 2 S.C.R. 373 at 433 (the executive branch has no power to legislate without statutory authorization); Entick v. Carrington (1765), 19 St. Tr. 1030, 95 E.R. 807 (K.B.) (most executive action interfering with citizen's rights requires statutory authorization); Goudie v. Langlois (1819), Stuart K.B. 142 (L.C.K.B.) (fees must be authorized by statute); Quebec (A.G.) v. Canada (A.G.). [1979] I S.C.R. 218 (public authorities require statutory authorization to be able to compel the attendance of witnesses or the production of documents); and $R$. v. Ward, [1999] N.J. No. 336 (C.A.) at para. 102, online: QL (NJ) (the power to impose penalties can be authorized only by Parliament). Beyond the field of coercive power, a more general principle requires a statutory basis for all official actions of public authorities established by legislation: Canada (Combines Investigation Act Director of Investigation \& Research) v. Newfoundland Telephone Company, [1987] 2 S.C.R. 466 at 478 . However, this does not preclude public corporate and/or prerogative entities from exercising contractual powers or managing property, and it does not appear to reach informal action such as the circulation of internal guidelines. 
At a more specific level, jurisdictional language provides only limited a priori guidance for intervention in judicial review cases. ${ }^{42}$ However, the presence or absence of jurisdiction may be relevant to the success of collateral attacks. ${ }^{43}$ Moreover, under natural justice and patent unreasonableness review, jurisdictional defects must meet a level of seriousness before courts will presume that the legislature intended not to authorize them. ${ }^{44}$ To this extent, jurisdiction can provide at least a notional threshold and justification for judicial intervention. These notions support a jurisdiction requirement in the context of issue estoppel. It is arguably unfair to subject a person to an administrative decision if this decision may have been so defective as to have been unauthorized.

The jurisdictional aspect of Ms. Danyluk's argument seemed to recall older, more rigid approaches rather than recent developments. Ms. Danyluk's main contention was that the breach of natural justice removed the judicial element required for issue estoppel. However, she also seemed to claim that because of the breach, there was no prior judicial decision to which issue estoppel could apply. ${ }^{45}$ The rationale was that a breach of natural justice immediately results in voidness from the outset, removing anything to which issue estoppel could apply. ${ }^{46}$ This looked like a claim that loss of jurisdiction automatically nullifies the entire legal status of a decision.

In response the Supreme Court could have pointed to significant academic support favouring a more relative approach to invalidity. ${ }^{47}$ On one hand, a decision without jurisdiction is usually regarded as void $a b$ initio. On the other hand, invalidity does not occur until and unless a decision is successfully challenged by a person with sufficient standing in the proper legal proceedings. ${ }^{48}$ It is then, and not before, that a decision is

However, in limited situations, where a statute expressly refers to jurisdiction or where the dispute involves constitutional capacity or boundaries between competing grants of administrative responsibility, jurisdiction may still help serve as an a priori determinant of validity: see Mullan, supra note 7 at 82.

13 Even after Maybrun, supra note 19 and R. v. Al Klippert Lid., [1998] I S.C.R. 737 [hereinafter Al Klippert], a lack or loss of jurisdiction in the original decision-maker is still relevant to the success of a collateral attack. If there is no alternative statutory remedy being considered, it should normally be a necessary requirement of such a successful collateral atlack under the old principle in Groenvelt v. Burwell (1700), 3 Salk. 354, I Ld. Ray. 454.

Under the unreasonableness and correctness standards, the barriers are lower but must still be met. "The Court of Appeal of Ontario erred in applying the doctrine of issue estoppel as there was no prior decision by a statutory officer acting judicially": Danyluk, supra note 1 (Appellant Mary Danyluk's factum), S.C.C. No. 27118 at para. 116.

"Issue estoppel cannot be applied to a decision which is void from the outset": ibid. at para. 82. See, e.g. H.W.R. Wade, "Unlawful Administrative Action: Void or Voidable?" (1967) 83 L.Q. Rev. 95 and (1968) 84 L.Q. Rev. 95; M.B. Akehust, "Void or Voidable? Natural Justice and Unnatural Meanings" (1968) 31 Mich. L. Rev. 2; D.P. Jones, "Discretionary Refusal of Judicial Review in Administrative Law" (1981) 19 Alta. L. Rev. 483; M. Taggart, "Rival Theories of Invalidity in Administrative Law: Some Practical and Theoretical Consequences" in M. Taggart, ed., Judicial Review of Administrative Action in the 1980s (Auckland, Melbourne: Oxford University Press in association with The Legal Research Foundation Inc., 1986) at 70-103; P.P. Craig, Administrative Law, 4th ed. (London: Sweet \& Maxwell, 1999) 660-75. In the context of the validity of Crown patents, this relative view of voidness was endorsed by a unanimous Ontario Court of Appeal in Chippewas of Sarnia Band v. Canada (A.G.) (2000), 51 O.R. (3d) 641 at para. 261.

As indicated by the Supreme Court itself in regard to bias see: $R$. v. Curragh, [1997] I S.C.R. 537 at para. 8 [hereinafter Curragh], discussed infra note 65 and accompanying text. 
retrospectively void. If this were not the case, it would be difficult to appeal a "decision" made without jurisdiction. ${ }^{49}$ The English writer Paul Craig has described this relative voidness as "retrospective nullity." 50

But instead of rejecting outright an absolute approach to jurisdictional invalidity, the Court said that some kinds of invalidity, including breaches of natural justice, have less far reaching effects. In taking this approach the Court revived an old concept of "initial jurisdiction," distinguished between void and "voidable" decisions, and left the implication that a lack of initial jurisdiction does result in absolute or at least automatic invalidity. The key passage said that

[o]nce it is determined that the decision-maker was capable of receiving and exercising adjudicative authority and that the particular decision was one that was required to be made in a judicial manner, the decision does not cease to have that character ("judicial") because the decision-maker erred in carrying out his or her functions. As early as R. v. Nat Bell Liquors, Ltd., [1922] 2 A.C. 128 (H.L.), it was held that a conviction entered by an Alberta magistrate could not be quashed for lack of jurisdiction on the grounds that the depositions showed that there was no evidence to support the conviction or that the magistrate misdirected himself in considering the evidence. The jurisdiction to try the charges was distinguished from alleged errors in "the observance of the law in the course of its exercise" (p. 156). If the conditions precedent to the exercise of a judicial jurisdiction are satisfied (as here), subsequent errors in its exercise, including violations of natural justice, render the decision voidable, not void: Harelkin $v$. University of Regina, [1979] 2 S.C.R. 561, at pp. 584-85. The decision remains a "judicial decision," although seriously flawed by the want of proper notice and the denial of the opportunity to be heard.

Later the Court talked in terms of whether the ESA officer stepped outside her judicial role and lost jurisdiction "for all purposes, including issue estoppel."

Thus the Court distinguished between (i) a want of [adjudicative] jurisdiction at the outset of a decision and (ii) other forms of reviewable defect, including breach of the rules of natural justice. According to the Court, defect (i) results in an absence of jurisdiction and a "void" decision. This result apparently removes automatically any legal "decision" (or "judicial" decision) that could give rise to issue estoppel. On the other hand, the Court suggested that natural justice and other defects in category (ii) do not result in an absence of jurisdiction - at least for the purposes of issue estoppel. ${ }^{53}$ Instead, they result in a "voidable" determination, leaving in place a legal "decision" (and a legal "judicial" decision) to which issue estoppel can apply.

A possible - but somewhat contrived - alternative is to construe a statutory appeal provision as including the power to hear an appeal from a nullity. This approach was suggested in Harelkin $v$. University of Regina, [1979] 2 S.C.R. 561 at 586 [hereinafter Harelkin]. Craig, supra note 47 at 665 .

Danyluk, supra note 1 at para. 47.

Ibid. at para. 48.

From the Court's apparent approval of the statement in R. v. Nat Bell Liquors, [1922] 2 A.C. 128 (H.L.) [hereinafter Nat Bell], it would seem to regard all defects other than a lack of initial jurisdiction as non-jurisdictional and "voidable" in their effect. From the qualification here, though, the Court seems to be suggesting that natural justice might be jurisdictional for some purposes and non-jurisdictional for others, such as the establishment of issue estoppel. 
It is not easy to find the logic behind the initial/subsequent jurisdiction distinction. If it is wrong to hold a party to a decision made without jurisdiction, it is not clear why this approach should be confined to the outset of a decision. A denial of a fair hearing before a properly constituted tribunal could seem as unfair as an adequate hearing by a tribunal that was improperly set up at the beginning. Conversely, some jurisdictional procedural defects, such as bias and want of independence, may be present at the very outset of proceedings. ${ }^{54}$ If this is so, it is confusing at least to treat lack of initial jurisdiction and breach of natural justice as mutually exclusive.

To support its initial jurisdiction approach the Court relied on the $1922 \mathrm{Nat}$ Bell decision..$^{55}$ Lord Sumner said there that jurisdiction can be lost or gained only at the outset of a decision. ${ }^{56} \mathrm{He}$ suggested that subsequent defects, such as lack of evidence, are non-jurisdictional or "less" jurisdictional in nature. But the Supreme Court expressly repudiated the concept of initial jurisdiction in its $1984 L^{\prime}$ Acadie decision. ${ }^{57}$ In the same year the Court expressly recognized that a lack of evidence can constitute a jurisdictional defect. ${ }^{58}$ Moreover, on numerous occasions, the Supreme Court has described breach of natural justice without qualification as a jurisdictional defect. ${ }^{59}$ In Maybrun, in the context of the collateral attack rule, the Supreme Court rejected the distinction between lack of jurisdiction $a b$ initio and loss of jurisdiction, saying that it is not easy to draw and should be avoided. ${ }^{60}$ Yet three years after Maybrun the Court revived this distinction for issue estoppel.

To support its void/voidable distinction, the Court referred to its 1979 decision of Harelkin. ${ }^{61}$ Harelkin supports an "adequate alternative remedies" principle in which courts may refuse judicial review if there is an adequate alternative remedy available. Here the Supreme Court declined to quash a decision affected by a breach of natural justice because Mr. Harelkin had an adequate alternative remedy by way of appeal. One of the majority's main reasons for refusing review was the proposition that breach of natural justice results in merely a "voidable" decision. In their view, this resulted in an

The classic example of a reasonable apprehension of bias, apparent at the very outset of proceedings, is Committee for Justice and Liberty v. Canada (N.E.B.), [1978] I S.C.R. 369.

Nat Bell, supra note 53.

Ibid. at 143.

Syndicat des employés de production du Québec et de l'Acadie v. Canada Labour Relations Board. [1984] 2 S.C.R. 412 at 438. See also Union des employés de service, Local 298 v. Bibeault. [1988] 2 S.C.R. 1048 at 1090; and Canadian Pacific Air Lines v. Canadian Air Line Pilots Assn., [1993] 3 S.C.R. 724 at para. 48, L'Heureux-Dubé J. dissenting on another point. unreasonableness as jurisdictional, see Paccar, supra note 34 at para. 19.

See, e.g., Forsythe v. The Queen, [1980] 2 S.C.R. 268; Alberla Union of Provincial Employees, Branch 63 v. Olds College, [1982] I S.C.R. 923; MacDonald v. Montreal (City of), [1986] I S.C.R. 460; Flamand, supra note 34 at para. 54; R. v. R.D.S., [1997] 3 S.C.R. 484 at para. 99 (referring to bias); Ellis-Don v. Ontario, [2001] I S.C.R. 221 at para. 114 (a dissenting judgment, but not contradicted by the majority on this point, and delivered by Binnie J.); Russell, supra note 34 at para. 20 (a unanimous nine-judge judgment).

Maybrun, supra note 19 at 48 and 49.

Supra note 49 at 584-85. 
"excess or abuse of jurisdiction," not a complete lack of jurisdiction. Thus the decision was not an absolute nullity that could not be appealed or "cured" by the appeal.

But the Harelkin majority had a second major reason for refusing judicial review. It was much broader, and it effectively undercut the need for the first. They said that courts have a discretion to refuse prerogative writs such as certiorari and mandamus, even where there is a lack of jurisdiction. ${ }^{62}$ The two main post-Harelkin, pre-Danyluk Supreme Court decisions upheld the alternative remedies principle because of the discretionary nature of judicial view, not the void/voidable distinction. ${ }^{63}$ They affirmed a general right to exercise this discretion, even for lack of jurisdiction. ${ }^{64}$ In Curragh, another post-Harelkin decision not mentioned in Danyluk, a majority of the Court said that a breach of the bias rule of natural justice renders a decision void, not voidable. They said that once a court finds that bias existed, it cannot be cured by statutory appeal. ${ }^{65}$ At the very least this suggests that Harelkin no longer supports a general equation between natural justice and voidable decisions.

There was good reason for the retreat from the void/voidable distinction. One of its difficulties is the many possible meanings of the term "voidable." ${ }^{166}$ Another problem is the implication that there are inherent categories of invalidity, depending on the defect, and that some are absolute. As suggested earlier, all invalidity is relative in the sense that it depends on successful legal proceedings, and then it normally has retrospective effect. ${ }^{67}$ Most uses of the term "voidable" are simply applications of retrospective invalidity ${ }^{68}$ or exceptions thought to be merited by special circumstances. ${ }^{69}$ Where

Three other judges, arguing that a breach of the rules of natural justice is a jurisdictional defect rendering a decision void, took a much narrower view of the court's discretion to refuse relief. Canada (Auditor General) v. Canada (Minister of Energy, Mines and Resources), [1989] 2 S.C.R. 49 at 93 (extending the discretion to declaratory relief); and Canadian Pacific v. Matsqui Indian Band, [1995] I S.C.R. 3 at para. 33, Lamer C.J.C. (as he then was) for six judges.

Ibid.

Curragh, supra note 48 at paras. 6 and 7, the majority decision of seven judges. Two dissenting judges said that a breach of natural justice renders a decision voidable. It must be added, though, that the majority interpreted void as meaning "not curable on appeal" and implied that some defects might be curable on appeal. Thus, while discarding the "voidable" terminology for bias, they assumed a form of void/voidable distinction for the purpose of statutory appeals.

For four possible meanings in English case law, see Craig, supra note 47 at 663-65. See also the discussion of the Canadian context, below.

The one general exception was the non-jurisdictional ground of error of law on the face of the record, which is probably now obsolete. It resulted in prospective invalidity.

Arguably, Harelkin, supra note 49 , falls in this category. It is really just an application of the notion that a decision has legal effect (and can be appealed) until such time as it is found to be void in a proper forum and that courts have a discretion to determine this forum. Whether or not a defect is curable by way of appeal relates to the appropriateness of the forum, not the nature of the invalidity. In Curragh, supra note 48 at para. 8, speaking in the context of ordinary court decisions, the Supreme Court said that "[c]ertainly, every order of a trial court is enforceable and must be obeyed until it is declared void by an appellate court. In this sense the order may be viewed as voidable" but then stressed that once it was declared, the invalidity was retrospective.

In municipal bylaw cases, a defect is often called voidable when what is really happening is an exercise of judicial discretion not to grant relief for a minor or technical infraction: see Immeubles Port Louis Ltée. v. Lafontaine (Village of), [1991] I S.C.R. 326. Similarly, a failure to afford a party a fair opportunity to be heard may be called voidable when a court is exercising its discretion to limit 
invalidity departs from this general norm ${ }^{70}$ this should depend on concrete justifications and not on blanket labels such as "voidable" rather than "void."

Not only were the distinctions in Danyluk complex, but they were arguably unnecessary. The essence of natural justice is a procedural failure that is so serious that it prejudices a party's right to have a claim properly considered. Such a failure is vulnerable to being struck down in a properly framed judicial review proceeding. If this is so, it is worth asking why a decision that is marred by a breach of natural justice should be able to give rise to an issue estoppel in the first place.

The inconsistency between the breach of natural justice and issue estoppel is demonstrated by the result in Danyluk itself. Finding that issue estoppel was not precluded, the Court then proceeded to consider if it should exercise its discretion to apply it. Here the Court considered the following factors:

1) the wording of the relevant legislation;

2) the purpose of the relevant legislation;

3) the availability of an appeal from the administrative decision;

4) the safeguards available to the parties in the administrative procedure;

5) the expertise of the administrative decision-maker;

6) the circumstances giving rise to the prior administrative proceeding, such as the complainant's circumstances and conduct; and

7) "a final and most important factor," the potential unfairness that could result from applying the issue estoppel doctrine. ${ }^{72}$

This is a useful list. Indeed, much of the policy discussion here shows the Court at it pragmatic best. However, its conclusion raises questions about the Court's earlier analysis. Under factor 1 the Court noted that the legislation at the time stated explicitly that "[n]o civil remedy of an employee against his or her employer is suspended or affected by this Act." ${ }^{23}$ Under factor 2 the Court said that putting excessive weight on the ESA decision by means of issue estoppel could encourage formality and undermine the Act's purpose of providing a fast and inexpensive means of resolving employment disputes. For factor 3 the Court said that because of the discretionary nature of the appeal provisions, there was no real right of appeal here. Under factor $5^{74}$ the Court considered that ESA officers lacked the legal training needed to deal with the potentially complex issue of contract law involved in Ms. Danyluk's claim, another consideration going against the application of

the invalidity of a decision to the parties directly affected: Medi-Dala Inc. v. Canada (A.G.), [1972] F.C. 469, at para. 21 (C.A.). As noted, supra note 67, the non-jurisdictional exception of error of law on the face of the record is now virtually obsolete.

For example, where it is felt that a particular defect is too trivial to merit judicial intervention or that it affects particular parties only.

As Craig argues, labels such as voidable (and non-jurisdictional) can conceal what is really happening. an exercise of judicial discretion to make an exception to the general principle of retrospective invalidity: Craig, supra note 47 at 669.

Danyluk, supra note 1 at paras. 67-80.

ESA, supra note 2, s. $6(1)$ as cited at para. 68 , ibid.

Factor 4 is considered below. 
issue estoppel. Under factor 6 the Court noted that the Ms. Danyluk started the ESA proceedings at a time of personal vulnerability, although she should bear some responsibility for including the large commission amount in her claims to the ESA.

This brings us to factor 7, the "most important factor." Under this factor the Court said:

Whatever the appellant's various procedural mistakes in this case, the stubborn fact remains that her claim to commissions worth $\$ 300,000$ has simply never been properly considered and adjudicated. ${ }^{75}$

It is important to see the basis for this conclusion. Under factor 4 the Court looked not only at the nature of $E S A$ procedure but at the $E S A$ officer's breach of natural justice. This, they said, was a "key factor" in Ms. Danyluk's favour. Indeed it was! The breach of natural justice was the reason Ms. Danyluk's claims had not been considered and adjudicated.

The Court might be suggesting that although a breach of natural justice does not automatically block issue estoppel, a sufficiently serious breach may. If so, what was the serious feature of this breach? The large sum of money involved? If so, what is the threshold? Would Ms. Danyluk have been bound by issue estoppel if she had claimed only $\$ 100,000$ ? Or $\$ 10,000$, the new $E S A$ claims limit established in $1996 ?^{76}$ What if she had been a single parent on welfare, claiming only $\$ 500$ in unpaid wages from a former parttime newspaper delivery job? Surely, what is important is the fact of prejudice - not its dollar amount and the denial of a fair opportunity to be heard. If this is so, a breach of natural justice should be sufficient to automatically preclude issue estoppel.

\section{Relation to Other Finality Doctrines}

A third major issue in Danyluk was the question of the relation between issue estoppel and other finality doctrines, such as the principle of adequate alternative remedies in Harelkin, above, and the rule against collateral attack in the 1998 Maybrun decision. ${ }^{77}$ The Supreme Court was rightly concerned that proceedings involving issue estoppel should not undermine the finality objectives behind these two doctrines. Ironically, its own suggested approach has the potential to do just this.

The Court said that the view that natural justice results in a loss of jurisdiction "for all purposes, including issue estoppel," would sidestep the alternative remedies approach in Harelkin. It would allow Ms. Danyluk to dispense with judicial review, ignoring the ESA decision as of right in her civil action. Technically, though, the alternative remedies principle would not be strictly applicable here in any event. It favours internal remedies over judicial review. It does not specifically favour internal remedies and judicial review over collateral attack.

Danyluk. supra note 1 at para. 80.

See Employment Standards Improvement Act, S.O. 1996, c. 23, s. 19(1). (Ms. Danyluk issued her statement of claim in March, 1994.)

Supra note 19. See also the companion decision to Maybrun, Al Klippert, supra note 43. 
The Court was closer to the mark in suggesting that a challenge to the jurisdiction of an administrative decision in a new process, in response to an issue estoppel claim, could undermine the rule against collateral attack:

The appellant's position would ... create an anomalous situation under the rule against collateral attack. As noted by the respondent, the rejection of issue estoppel in this case would constitute, in a sense, a successful collateral attack on the ESA decision, which has been impeached neither by administrative review nor judicial review. On the appellant's theory, an excess of jurisdiction in the course of the ESA proceeding would prevent issue estoppel, even though Maybrun ... says that an act in excess of a jurisdiction which the decision-maker initially possessed does not necessarily open the decision to collateral attack. It depends, according to Maybrun, on which forum the legislature intended the jurisdictional attack to be made in, the administrative review forum or the court. ${ }^{78}$

However, Maybrun said that for the purposes of collateral attack, although the jurisdiction of the original decision-maker is a relevant factor, ${ }^{79}$ what is not relevant to determining the appropriate forum is whether there has been a lack of jurisdiction at the outset or invalidity resulting from a loss of jurisdiction. ${ }^{80}$ Thus the Danyluk notion that a lack of jurisdiction from the outset prevents issue estoppel, and presumably can be challenged collaterally, seems inconsistent with the Maybrun approach. Danyluk does bring other defects within the ambit of Maybrun, but there may be a better way of doing this. Indeed, there may be a better general alternative to the issue estoppel approach taken in Danyluk.

\section{SUGGESTION}

It is now possible to summarize three recurring general questions about Danyluk, which might help set the context for an alternative approach to finality. First, why should a decision which is marred by a breach of natural justice give rise to issue estoppel in the first place? Second, why should any defect that is serious enough to invalidate a decision in judicial review proceedings be protected by issue estoppel ? $^{81}$ Third, why should extensive issue estoppel analysis be required where what is really involved is a collateral attack?

The following approach could address these questions and could overcome many of Danyluk's complexities. Where an issue estoppel claim is resisted by a challenge to the jurisdiction of an administrative decision, this proceeding should be analyzed first in terms of the rule against collateral attack. The question of the forum for challenge should

Danyluk, supra note 1 at para. 49.

Maybrun, supra note 19 at paras. 47-48, 67.

lbid.

Today not only a breach of natural justice but also an incorrect decision where correctness is required. an unreasonable decision where reasonableness is required, and a patently unreasonable decision where patent unreasonableness is precluded are all deemed sufficiently unjust and serious to merit judicial review in appropriate proceedings; why should a different approach be taken to issuc estoppel? Like breach of natural justice, incorrectness, patent unreasonableness, and probably also simple unreasonableness all go to competence or jurisdiction; why should a different approach be taken to issue estoppel? 
precede the question of the merits of the challenge. If the collateral attack is then allowed to proceed, any finding of lack or loss of jurisdiction - including breach of the rules of natural justice - should preclude the establishment of issue estoppel. If there is no jurisdictional defect to preclude issue estoppel, the "judicial" requirement should be the application of an objective legal standard to findings of fact, except in investigative and legislative contexts.

On the approach suggested here, Danyluk would be a collateral attack case, not an issue estoppel case. Issue estoppel would be precluded where the administrator lacked jurisdiction - for breach of natural justice or for any other substantive grounds of review. Because Ms. Danyluk had clearly been denied natural justice, the appropriate framework for considering whether she should be able to relitigate would be the rule against collateral attack in Maybrun.

Maybrun requires a court to balance the need for administrative effectiveness with the need to ensure that government exercises its powers according to law and that citizens be able to assert their rights. Maybrun says that the key question is the legislator's intention as to the appropriate forum for challenge. As it does under the principle of alternative remedies, an adequate administrative appeal process militates strongly against external challenge.

In Ms. Danyluk's case, a Maybrun-based collateral attack analysis could address these questions in light of factors quite similar to those considered in Danyluk itself, including:

1) the wording of the statute from which the power to issue the order derives;

2) the purpose of the legislation;

3) the availability of an appeal; and

4) the nature of the collateral attack. ${ }^{82}$

Maybrun itself is a work in progress. The Court stressed there that its factor list is not exhaustive. Three obvious candidates for inclusion are the availability of review as well as appeal, the expertise of the relevant decision-makers, and the conduct of the party seeking the collateral challenge ${ }^{83}$ Moreover, Maybrun itself needs greater clarity about the effect of the presence or absence of jurisdiction in the original administrative decisionmaker. ${ }^{84}$ Among the factors it did list, though, Maybrun put very great weight on

82 Maybrun, supra note 19 at para. 15, citing the factors of Laskin J.A. of the lower court (1996), 28 O.R. (3d) 161 (C.A.).

*3 Conversely, the Maybrun list included a factor that is relevant only in enforcement proceedings: the penalty on a conviction for failing to comply with the enforcement order, ibid.

Maybrun, ibid., rightly stresses that an absence of jurisdiction in the decision of the original administrative decision-maker - a situation the Court assumed "for discussion purposes" (at para. 49) in that case - is not conclusive of the legislator's intentions regarding the appropriate forum for challenging the decision. See also Al Klippert, supra note 43 at para. 20. For example, the presence of an adequate administrative appeal will be strong evidence of the legislator's intention to route challenges that way, instead of through collateral attack. On the other hand, absence of jurisdiction in the original administrative decision should be clearly recognized as a relevant but not necessarily sufficient condition of a successful collateral attack, and a necessary condition where there is no alternative statutory remedy under consideration. Conversely, the presence of jurisdiction in the 
factor 3. Indeed, thus far, the rule against collateral attack looks a lot like the alternative remedies principle for judicial review. For Ms. Danyluk it would be especially significant that the ESA appeal was not automatic but discretionary. Moreover, in this case, the statute expressly left the door open to civil litigation. The absence of statutory requirements for appellate legal expertise or representation could also be relevant, especially for a potentially complex contractual claim.

Rather than complicating or weakening law on administrative finality, this suggested approach would help simplify it. True, the approach would not remove complex issue estoppel requirements, such as finality, sameness, parties or privies, and mutuality. However, under this approach issue estoppel would be a residual and exceptional means of enforcing finality, not a parallel to the rule against collateral attack. Where issue estoppel did apply, the "judicial" requirement would be more coherent, and there would be no need for fine distinctions between different categories of defect. Invalidity would be seen as the result of a successful challenge in a proper legal forum, not as an absolute. The main focus would shift to the rule against collateral attack, with its emphasis on the appropriate forum. The way would be clear for the Supreme Court to consolidate the present doctrine of alternative remedies and collateral attack into a general alternative remedies principle based on the notion of the appropriate forum intended by the legislator.

\section{CONClusion}

When they search for a balance between administrative fairness and finality, courts should take the shortest route. Issue estoppel fits uneasily into administrative law contexts. It should play only a limited role in a broader finality approach based on Maybrun. This approach might not have changed the result in Danyluk itself. A court might well conclude that Ms. Danyluk had no adequate alternative forum to civil litigation. However, a Maybrun-based approach offers a simple alternative to roundabout excursions in issue estoppel. Moreover, it puts the ball - the main responsibility for allocating the forums

of administrative decision-making - back firmly into the hands of the legislator.

original administrative decision should clearly preclude collateral attack, at least where this attack is based on common law grounds such as the common law torts. In their concern to stress the importance of the jurisdiction of appellate decision-maker, Maybrun and Al Klipperf neglect its potential significance in the original decision-maker. 